\title{
The Influence of Russian Piano School on Chinese Piano Art
}

\author{
Peng Sun \\ Department of Music \\ Xiamen University Tan Kah Kee College \\ Xiamen, China
}

\begin{abstract}
The Russian Piano School shows its own uniqueness in music creation, music performance, music teaching and so on. The development of Chinese piano art is deeply influenced by Russian piano art. In the new historical period, in order to better promote the development of Chinese piano art, it is very necessary for piano artists to strengthen the understanding of Russian piano art. Based on the analysis of the development and characteristics of Russian piano school, this paper analyzes the influence of Russian Piano School on the development of Chinese piano art.
\end{abstract}

Keywords-Russian piano school; formation; characteristics; Chinese piano art; influence

\section{INTRODUCTION}

The Russian piano school has its own strong national characteristics. The musicians of the Russian pianist school have explored and developed the music of the nation, summed up the characteristics of the pianist schools of the various periods, and on this basis, formed a characteristic Russian piano art based on the needs of the development of the times. The Russian piano school pays attention to sound voice training and full emotional expression, and applies the advanced European piano deduction technique training method, and finally forms a unique piano art training system. Since the last century, the Russian piano school has enjoyed a high reputation worldwide and has had a profound impact on the development of piano art in various countries. As to how the Russian piano school is formed and developed, what are the characteristics of the Russian piano school and how the development of the Chinese piano art has been influenced, the thesis will make an exploration in order to better spread and develop the Russian Piano Art and promote the development of Chinese piano art.

\section{THE FORMATION AND DEVELOPMENT OF THE RUSSIAN PIANO SCHOOL}

In the Nineteenth Century, the Czar court introduced the modern piano from Western Europe, and invited professional pianists to give lectures. The main teaching objects were aristocratic children. After that, piano music became popular in the palace and attracted more and more foreign pianists to visit the Czar court. In the exchange of learning with foreign piano art, the Czar Court (later Russia) laid a good foundation for its piano art development. In 1840s, the Russian piano art began to spread to all parts of the world, and formed a school of music specializing in the teaching of piano art and created the piano music school.

\section{THE CHARACTERISTICS OF THE RUSSIAN PIANO SCHOOL}

\section{A. Its National Characteristics}

Russian piano music composers blended folk music, poetry, drama, literature, natural scenery and humanistic style which are unique in Russia into piano music and reflected them in the form of music and expressed them with the unique Russian national language. In Russian piano music, some are to express the missing to their friends; some are praise of the natural scenery; some are odes of labor of people; some are to express their wishes and imagination for the future. Generally speaking, Russian piano music embodies the unique Russian national characteristics, reflecting the development of Russian folk art and language.

At the beginning of the Twentieth Century, several Russian pianists and composers made a great contribution to the development of Russian piano music. They were Rachmaninoff, who represented the strong romantic style, Scriabin, who was known as "Chopin of Russia", Prokofiev, who represented neoclassicism, Shostakovich and Kabalevsky of modern style. Although they were different in character, they have distinctive national characteristics in the artistic composition of the piano. The works of these piano artists have deeply influenced the development of the world's piano art. They were important persons to push the Russian piano art to the world.

\section{B. The Singing Character of National Music Style}

Russian piano music emphasizes singing, which emphasizes combining the melody of the song with the melody of piano music in the composition and expounds the characteristics of the piano tone through the view of vocal music. It requires the expression of the rich emotion in the singing of the human voice in the piano music art. At the same time, it emphasizes the expressive force of music in the piano music performance. On the one hand, the piano music should be lyric. On the other hand, it shall express the spirit of romanticism. The content of the works and the personal feelings of the piano musicians can be effectively combined, 
and expresses the artistic charm of piano music through delicate treatment.

\section{The Experiencing Character of National Artistic Nature}

The Russian people are bold, enthusiastic, and able to sing and dance. In pursuit of personal development, they prefer to follow their inner voice rather than proceed entirely according to reason. In the artistic creation of the piano, Russian composers emphasize the perceptual experience and the description of the beautiful images, and emphasize the artistic appeal of the piano works, not the stereotyped reproduction of the art.

In the expression of the piano art, the Russian piano performance artists tend to be loyal to the original piano art, and express their understanding of the piano art on the basis of the original work, and are opposed to showing off the piano technique and the exaggerated performance skill and the detachment from the content.

\section{The Superb Piano Performance Skills}

Another characteristic of Russian piano music is the great Russian piano performance school, which has born a large number of performing artists, such as Richter, Gilels and Pletnev. Their superb skills, wonderful voice and profound musical ideas have influenced the world so far. There also appeared great piano educators, such as Negoz and Gordon Witzel. They emphasized that in the process of playing the piano, the player's fingers shall be strong, the style shall be accurate and the rhythm shall be strong, and players shall show their unique feelings on music. In touching key, they emphasized "deep key touching", and to use the playing method of weight. Don't blindly use the key touching method that doesn't pay attention to sound. In expression of music, they emphasized to hear one's inner heart. It requires performers have personal emotional pursuit on the basis of respecting the composer's style.

\section{THE INFLUENCE OF RUSSIAN PIANO SCHOOL ON CHINESE PIANO ART}

\section{A. The Influence of Russian Piano Teaching Materials}

In Chinese piano teaching, we have always lacked a systematic and standardized set of teaching materials and teaching methods. Our piano art and piano education are in the primary stage of development. In piano teaching, mostly teachers teach dominantly and students learn passively. In selection of teaching materials, we are limited to Beyer, Hanon, Cherney 599, 849, 299, A Collection of Sonatas, which is not conducive to students' deepening study of piano art, and to a great extent, the deepening of the development of Chinese piano art.

The Russian piano teaching materials have the characteristics of professionalism and nationality, and most of them are the works of their own piano composers. In the basic teaching of the piano, there is no single designation of which composer's works to be studied, but the emphasis on the comprehensive analysis of many writers in the same period and different periods, and on diversity of teaching materials and comprehensiveness of learning. The characteristics of Russian piano teaching materials determine that the teaching emphasizes the combination of singing and performing skills and opposes a large number of mechanized and repetitive practices. The teaching material of Russian piano music contains a variety of music of different styles, including folk songs, variations, ensembles and polyphonic works. Through the study of a variety of themes, it tells people that piano learning focuses on the performance of piano music based on a certain technique. The richness and perfection of Russian piano music materials make up for the shortage of Chinese piano music teaching materials, so that Chinese students majoring in piano music have been greatly improved in playing skills and music performance in learning piano music.

\section{B. The Appearance of Chinese Style Piano Music under the Influence of Russian Piano Artists}

The earliest display of the composition of Chinese piano music was in a competition for Chinese flavor piano music which was held by a Russian pianist in 1934. In this competition, He Lulin's Shepherd Boy's Flute and Lullaby, and Jiang Dingxian's Lullaby and many other works have showed Chinese flavor piano works. Around 1938, influenced by China's political development, patriotic films and songs were popular in China, and the development of Chinese piano art was rather slow. In this period, the piano music created by Ding Shande has a profound influence on the development of Chinese piano art. It mainly manifested in his composition Spring Tour and the theme variations of Chinese folk songs which have provided important support for the development of Chinese piano art. In 1955, China sent Chinese composers to the Soviet Union to study in the Soviet Union. Later, influenced by Russian piano art, they composed Flower Drum which was a piano music work full of fresh vitality and ethnic characteristics. Then, in 1956, Huang Huwei, Chinese piano composer, continued to learn from a Soviet piano music professor and wrote Bashu Painting which highly praised the nature. He has made an important contribution to the development of Chinese piano career. So, Russian piano art has a great influence on Chinese piano art.

Under the profound influence on the development of piano art in China, we have employed a well-paid Russian pianist Chaharov to teach our students in piano music. Chaharov was students of Anna Yeipova, the earliest founder of Russian piano school. He worked in Shanghai National Music College after being hired. Under his efforts our piano art began to recover and develop quickly, trying to catch up with the tide of international piano art performance and realize the internationalized development of piano art. The Russian pianist Chaharov paid great attention to the basic skill practice of fingers in the piano art teaching, which has a profound influence on our piano education at various stages. For example, when the pupils are learning the piano, they are asked to have the feeling of holding an egg in their hands; students majoring in piano music shall receive technique inspection every year, and the items inspected include fingering practice of Hanon, musical scale, arpeggio, dual-tone scale and octachord. And students shall reach certain playing speed. It can be seen basic skill is paid with great attention in 
learning of piano music. With the establishment and continuous development of the new China, many pianists who have studied in Russia began to return back and teach in China. More students majoring in piano music were sent to Russia to study, and Chinese piano art has developed rapidly at a time. Li Shikun and Yin Chengzong were earliest Chinese pianists who have been studied in Russia and got prize in the international stage. At that period they got many international piano prizes. It can be said that the Russian pianist school is the first piano school to influence China.

\section{Russian Piano Art Enriches and Improves Chinese Piano Teaching Methods}

In the 1940s, the development of Chinese piano was slow. Many piano teachers used traditional piano playing methods in Europe. They paid attention to the movement of fingers without moving finesse in playing piano and the coordination of body in piano performance. But they didn't stress the power in touching key and expressive force of piano music. In teaching of piano, teachers only emphasized the performance skills and neglected the connotation of piano music. The Russian piano teaching mode has a profound influence on the traditional piano education in China. For example, Russian pianists paid attention to the standard teaching in piano class, which put forward high requirements on piano playing quality of teachers. In explanation of piano music works, Russian piano teachers have deep understanding of its performing methods, creation background and connotation of music. At same time, they also pursue the singing character of music melody in performance, and learn the weight figuring method from Russian piano school teaching of piano music. In performance, it is not only simple touch of figures and keys, but also the expression of strength of fingertip, forming abundant interaction between figures and music. It can better express the musicality of the work. The leaping progress of Russian piano music has played a very important role in the development of Chinese piano art.

\section{CONCLUSION}

To sum up, it is to better develop the cause of Chinese piano art to understand the history of Russian piano music and the characteristics of Russian piano school. The development of the Russian national music school has provided us with a good precedent. The performance of Chinese piano art, and teaching and creation of piano music should also reflect the characteristics of Chinese history, politics, economy and culture. Western countries are different from Chinese society in development way, and Russia is relatively similar to China. The Russian piano art has a great influence on the development of Chinese piano art, and provided important support for emergence and recreation of excellent Chinese piano artists. To this end, in the development of economic globalization, in order to push the Chinese culture to the world, Chinese piano art shall shine our own irradiance in understanding and learning from the essence of Russian piano art, and show our national characteristics. Only it is national, it is international.

\section{REFERENCES}

[1] Zhu Zhenkun. The Influence of Russian Piano School on Piano Education in China. Art Education, 2016, 02: 104. 朱振坤. 俄罗斯钢琴 学派对我国钢琴教育的影响探究[J]. 艺术教育,2016,02:104.

[2] Jing Peng. Influence of Opera Music Elements on Chinese Piano Art. Music Creation, 2016, 06: 108-109. 景鹏. 论戏曲音乐元素对中国钢 琴艺术的影响[J]. 音乐创作,2016,06:108-109.

[3] Lu Yang. The Influence of Russian Piano School on Piano Education in China. Drama House (first-half month), 2014, 05: 120. 路阳. 俄罗斯钢 琴学派对我国钢琴教育的影响研究 [J]. 戏剧之家 (上半 月),2014,05:120.

[4] Zhang Lin. The Influence of Opera Music Elements on Chinese Piano Art. Contemporary Drama, 2011, 03: 48-49. 张琳. 戏曲音乐元素对中 国钢琴艺术的影响 [J]. 当代戏剧,2011,03:48-49.

[5] Wang Jia. The Influence of Russian Piano Art on Chinese Piano Art Voice of Yellow River, 2011, 11: 112-113. 王佳. 俄罗斯钢琴艺术对我 国钢琴艺术的影响初探[J]. 黄河之声,2011,11:112-113.

[6] Xu Lan. The Influence of Opera Music Elements on Chinese Piano Art. Journal of Jiamusi Career Academy, 2015, 04: 304-305. 徐澜. 探究戏 曲音乐元素对中国钢琴艺术的影响 [J]. 佳木斯职业学院学 报,2015,04:304-305.

[7] Wang Yixuan. Influence of Russian Piano School on the Piano Art in China. Science and Education Guide (midmonth), 2010, 08: 247-248. 王艺璇. 论俄罗斯钢琴学派对我国钢琴艺术的影响 [J]. 科教导刊(中 旬刊),2010,08:247-248.

[8] Jin Di. The Influence and Enlightenment of Russian Piano Art Achievements on the Development of Chinese Piano Art. Literary Criticism, 2010, 06: 92-96. 金荻. 俄苏钢琴艺术成就对中国钢琴艺术 发展的影响和启示[J]. 文艺评论,2010,06:92-96. 